\title{
The Compressive and Flexural Strength of Self Compacting Concrete Using Rice Husk Ash and Limestone
}

\author{
M. Iroh, J.E.O.Ovri, U. Nwachukwu \\ Department of Materials and Metallurgical Engineering, Federal University of Technology Owerri
}

\begin{abstract}
The Compressive and Flexural Strengths of Self Compacting Concrete SCC produced by the replacement of 100\%Ordinary Portland Cement (OPC) with the Mix of Rice Husk Ash (RHA), Limestone (LS) and Ordinary Portland Cement $(O P C)$ is the subject of this investigation. Concrete Specimens were produced with O\%RHA, 5\%RHA, 10\%RHA, 15\%RHA, 20\%RHA,5\%RHA1\%LS, 10\%RHA2\%LS, 15\%RHA5\%LS, $20 \%$ RHA $7 \%$ LS with the remaining percentage as Ordinary Portland cement (OPC), added with fine aggregates, coarse aggregates and water were cured for a period of 28 days. The cured specimens were subjected to compressive and flexural tests to determine their strengths. Optimum compressive and flexural strengths of $20.62 \mathrm{~N} / \mathrm{mm}^{2}$ and $6.43 \mathrm{~N} / \mathrm{mm}^{2}$ respectively were obtained for a Mix of 10\%RHA2\%LS88\%OPC which was higher than the compressive strength of $19.56 \mathrm{~N} / \mathrm{mm}^{2}$ for $100 \%$ OPC.
\end{abstract}

Keywords: Rice husk, Concrete, Portland cement, Compressive, Flexural Strength

\section{INTRODUCTION}

Concrete is the single most used construction material in the world due to its several unique properties and its wide range of use in various types of works. It is made from cement, aggregate and water with the occasional addition of an admixture ${ }^{1}$. Some of the desirable properties of concrete include strength and durability, low cost of maintenance, affordability, fire resistance, thermal mass, versatility, minimal waste etc. The strength of concrete is affected by some factors such as quality of raw material, water/cement ratio, coarse/ fine aggregate ratio, and age of concrete, compaction of concrete, temperature, relative humidity and curing of concrete. Because of its universal usage and wide application it becomes absolutely necessary to reduce the cost of producing this concrete and at the same time improve on its properties.

\subsection{Survey}

The earliest use of cement dates back to when civilization first started. Although the history of Portland cement is comparatively short, but the use of the structural binding agent dates back thousands of years. One of the earliest examples is that of the water tanks at Aden which were constructed 6000BC and is still in use today.

Analysis of the mortar used by the Egyptian in the construction of the pyramid of Cheops at about 3600BC show that they possessed a good practical knowledge of this subject at that time. The Greeks at a very early period of their civilization, used compositions of lime as a base to cover wall. In Italy the first people to employ mortar in their building were the Etruscans.

During the first part of the Eighteenth century, very little progress was made with the evolution of cement. In 1756, an Engineer John Smeaton gave a serious attention to the principle of setting lime under water and found that by mixing lime and pozzolana, a substance was produced which became hard and solid with the addition of water. Although this was not Portland cement but it was a vast improvement over lime mortars. The French Vicat went a step further by burning pulverized chalk and clay together in the form of a paste. He discarded and burnt the very portion which would have given them Portland cement. Smeaton's discovery led to a rapid improvement in cement and masonry construction.

In 1824 an English man Joseph Aspdin found that by mixing finely pulverized clay in specified proportion, burning them to a high temperature and then grinding the resultant clinker, it was possible to produce a hydraulic binding material far superior to any products known at that time. It was Aspdin who named it Portland cement because when set, it looked like Portland stone ${ }^{3}$. 


\subsection{Portland Cement and Rice Husk Analysis}

\subsubsection{Cement}

Is and has remained one of the most important raw materials in the production of structural parts in the construction industry. It is an extremely fine ground product obtained by burning together at high temperature specially proportioned amounts of calcareous and argillaceous raw materials adding nothing else to the burnt product except gypsum in a small percentage ${ }^{4}$. In general it is an adhesive substance which has binding capabilities used in building and civil engineering construction.

Ordinary Portland cement is the most common type of cement and is classified into three grades: namely 33 grades, 43 grades and 53 grades depending on the strength of the cement after 28days when tested based on ISO4031-1988. If the 28 day strength is less than $43 \mathrm{~N} / \mathrm{mm}^{2}$, it is called 43 Grade cement, and if the strength is not less than $53 \mathrm{~N} / \mathrm{mm}^{2}$. It is called 53 Grade cement. But the actual strength obtained by these cements at the factory is much higher than the BIS specification ${ }^{5}$.

The principal raw materials used in the manufacture of cement are

a) Argillaceous or silicates of alumina in the form of clays and shale

b) Calcareous or calcium carbonate in the form of limestone, chalk and marl which is a mixture of clay and calcium carbonate

Table1. Normal Composition of the Ordinary Portland Cement ${ }^{6}$

\begin{tabular}{|l|l|}
\hline Oxide & Percentage \% \\
\hline Lime $(\mathrm{CaO})$ & $60-67$ \\
\hline Silica $\left(\mathrm{SiO}_{2}\right)$ & $17-25$ \\
\hline Alumina $\left(\mathrm{Al}_{2} \mathrm{O}_{3}\right)$ & $3-8$ \\
\hline Iron oxide $\left(\mathrm{Fe}_{2} \mathrm{O}_{3}\right)$ & $0.5-6$ \\
\hline Magnesia $(\mathrm{MgO})$ & $0.1-4$ \\
\hline Sulphur Trioxide $\left(\mathrm{SO}_{3}\right)$ & $1-3$ \\
\hline Soda and or potash $\left(\mathrm{Na}_{2}+\mathrm{K}_{2} \mathrm{O}\right)$ & $0.5-1.3$ \\
\hline
\end{tabular}

\subsubsection{Rice Husk}

These are finely fragmented or divided particles of grain waste product measuring less than about $1 / 9 \mathrm{~mm}$ in diameter and which is obtained from removal of rice grain from its shell called husk. It is one of the most widely available agricultural wastes in many rice producing countries around the world. On average $20 \%$ of the estimated 600 million tons of rice produced annually is husk. Rice husk contains $75-90 \%$ organic matter such as cellulose; lignin etc and the rest are mineral components such as silica. The content of each depends on rice variety, soil chemistry, climatic condition and even the geographic location. Rice husk application depends on its physical and chemical properties such as ash and silica content. It has been directly used as fuel in power plants and also as source of raw material for synthesis and development of new phases and compounds.

\subsection{Flexural and Compressive Strength}

Flexural strength is a measure of the tensile strength of concrete. It is a measure of the ability of an unreinforced concrete beam or slab to withstand failure in bending. It is measured by loading $150 \times 150 \mathrm{~mm}$ concrete beams with a span length at least three times the length. The flexural strength is measured in Modulus of Rupture (MR),Psi or MPa and is determined by standard test methods ASTM C78 (third point loading) or ASTM C 293(centre point loading).

Compressive strength is the capacity of a material or structure to withstand loads tending to reduction size. It can be measured by plotting applied force against deformation in a testing machine. It is often measured on a universal testing machine and these range from small table top system to ones with over $53 \mathrm{MN}$ capacity.

\subsection{Objective of the Study}

a) To improve the compressive and flexural strengths of concrete by partial replacement of Portland cement with RHA and Limestone

b) To develop means of utilizing Rice Husk Ash in order to mitigate the attendant environmental pollution resulting from its disposal

c) To reduce the cost of concrete production by reducing the cost of its raw materials. 
The Compressive and Flexural Strength of Self Compacting Concrete Using Rice Husk Ash and Limestone

\section{EXPERIMENTAL}

\subsection{Material Preparation}

Ordinary Portland Cement of type 1 ASTM C-150 manufactured by Ibeto Company Nigeria Plc was used in this work along with Rice Husk Ash (RHA), Limestone (LS), fine and coarse aggregates and water.

The rice husk obtained from Anambra state was burnt in a muffle furnace at a temperature range of $650-850^{\circ} \mathrm{C}$ for about 30 mins. This furnace product was reduced to finer form and used for concrete cube production. The limestone obtained from Nkalagu Ebonyi State Nigeria was air- dried, milled and grounded. The coarse aggregate used was crushed gravel of $12.5 \mathrm{~mm}$ size obtained from Otamiri River in Owerri. Pure water from borehole was used and concrete bars were cast and tested for compressive and flexural strength.

\subsection{Compressive/Flexural Strength}

Compressive strength was calculated using the relation

$\sigma_{\mathrm{c}}=\mathrm{F} / \mathrm{A}$

Where $\sigma_{\mathrm{c}=}$ compressive strength

$\mathrm{F}=$ load at failure

A $=$ cross sectional area of concrete cube.

FLEXURAL STRENGTH

$\sigma_{\mathrm{B}=} 3 \mathrm{pa} / \mathrm{bd}^{2}$

WHERE

$\mathrm{P}=$ Failure Load N

$\mathrm{a}=$ distance between loading pins $(150 \mathrm{~mm})$

$\mathrm{b}=$ Breadth of the specimen $(150 \mathrm{~mm})$

$\mathrm{d}=$ Height of the specimen $(150 \mathrm{~mm})$

\section{RESUlTS}

Table2. Results of Chemical Analysis of Rice Husk Ash, Ordinary Portland cement and Limestone

\begin{tabular}{|l|l|l|l|}
\hline$\%$ & $\% \mathrm{OPC}$ & \%RHA & \%LS \\
\hline $\mathrm{SiO}_{2}$ & 28.03 & 63.45 & 5.9 \\
\hline $\mathrm{Al}_{2} \mathrm{O}_{3}$ & 4.88 & 2.12 & 1.3 \\
\hline $\mathrm{Fe}_{2} \mathrm{O}_{3}$ & 3.98 & 2.18 & 0.77 \\
\hline $\mathrm{CaO}$ & 64.67 & 1.21 & 49.74 \\
\hline $\mathrm{MgO}$ & 2.34 & 1.35 & 0.99 \\
\hline $\mathrm{SiO}_{3}$ & 2.75 & 0.12 & - \\
\hline $\mathrm{Na}_{2} \mathrm{O}$ & 0.17 & 1.59 & - \\
\hline $\mathrm{K}_{2} \mathrm{O}$ & 0.58 & 0.96 & - \\
\hline $\mathrm{PbO}$ & 0.07 & - & - \\
\hline $\mathrm{TiO}$ & 0.35 & - & - \\
\hline $\mathrm{LOI}(1000)$ & - & 5.25 & 40.12 \\
\hline
\end{tabular}

Table3. Compressive Strength of Self Compact Concrete at Different Percentages of Rice Husk Ash Replacement

\begin{tabular}{|l|l|}
\hline Percentage replacement & Compressive strength $\left(\mathrm{N} / \mathrm{mm}^{2}\right)$ \\
\hline 0(CTL) & 19.56 \\
\hline 5\% RHA 95\% OPC & 18.58 \\
\hline $10 \%$ RHA 90\% OPC & 19.33 \\
\hline 15\% RHA 85\% OPC & 16.09 \\
\hline 20\% RHA 80\% OPC & 12.09 \\
\hline 5\% RHA 1\% \%S 88\% OPC & 20.09 \\
\hline 10\% RHA 2\% LS 88\% OPC & 20.62 \\
\hline 15\% RHA 5\% LS 80\% OPC & 11.56 \\
\hline $20 \%$ RHA 7\% LS 73\% OPC & 2.98 \\
\hline
\end{tabular}


Michael Iroh et al.

Table4. Results of Flexural Strength of Self Compact Concrete with Different Percentages of Rice Husk Ash Replacement and Limestone

\begin{tabular}{|l|l|}
\hline Percentage Replacement & Flexural Strength $\left(\mathbf{N} / \mathbf{m m}^{2}\right)$ \\
\hline O(CTL) & $\mathbf{7 . 4 7}$ \\
\hline 5\% RHA 95\% OPC & 6.10 \\
\hline $10 \%$ RHA 90\% OPC & 6.37 \\
\hline 15\% RHA 85\% OPC & 5.20 \\
\hline 20\% RHA 80\% OPC & 5.00 \\
\hline 5\% RHA 1\%LS 88\% OPC & 5.83 \\
\hline $10 \%$ RHA 2\%LS 88\%OPC & $\mathbf{6 . 4 3}$ \\
\hline 15\% RHA 5\%LS 80\% OPC & $\mathbf{5 . 3 3}$ \\
\hline 20\% RHA 7\%LS 73\%OPC & $\mathbf{4 . 7 3}$ \\
\hline
\end{tabular}

Figure 1: Compressive Strength against \%Replacement
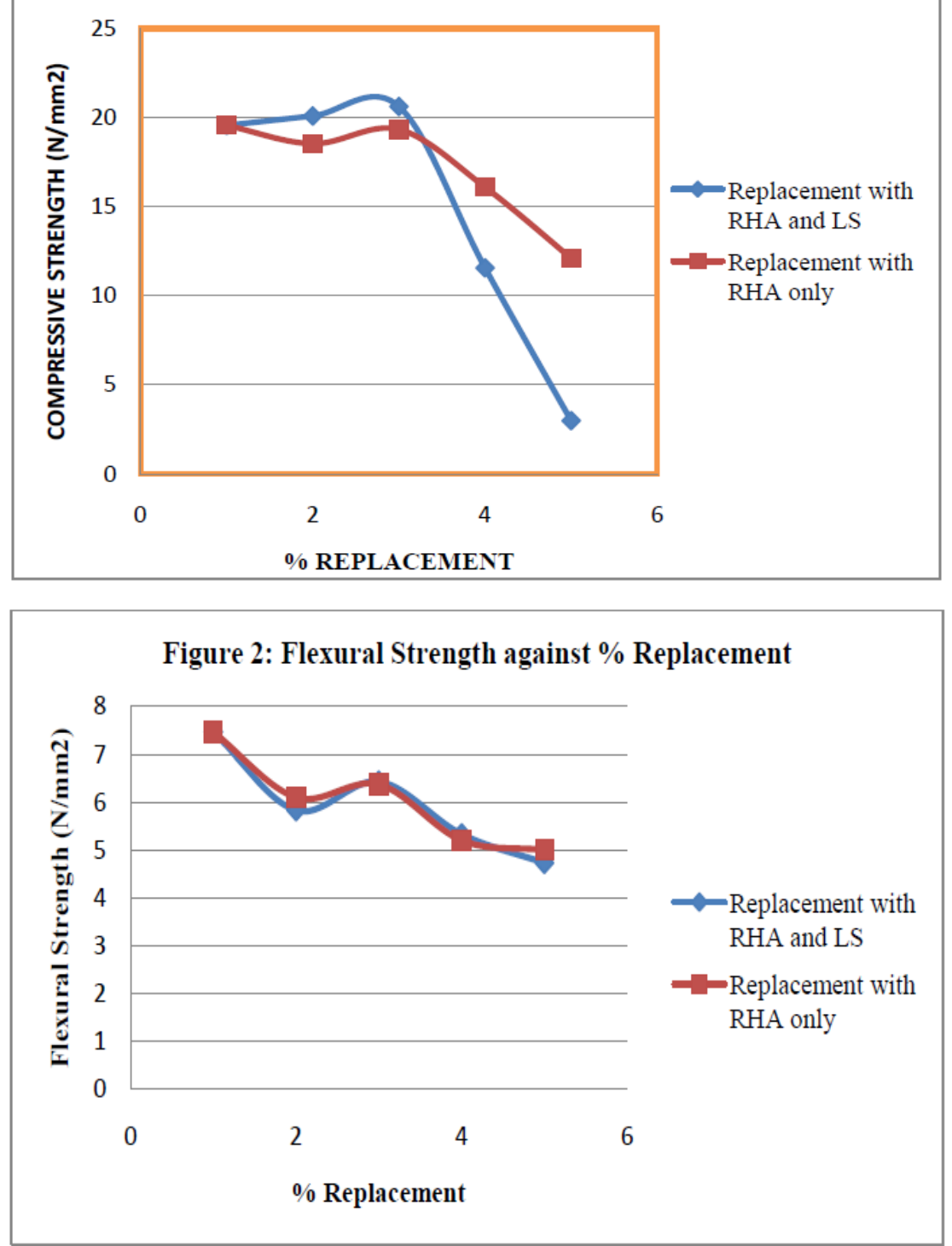

\section{Discussion OF RESUlts}

\subsection{Chemical Analysis Of Rha, Opc and Ls}

The chemical analysis of the RHA, OPC and LS results, shown in Table 2 shows that the silica content of the RHA was $63.45 \%$ which is higher than that of OPC and LS. This value is closer to the required $70 \%$ minimum for Pozzolans ${ }^{7}$ and is slightly less than the value of $67.30 \%$ as reported ${ }^{8}$ 
Alumina content was higher in OPC than in RHA.Although the hydrated aluminates $\mathrm{C}_{3} \mathrm{Al}$ do not contribute to the strength of the concrete. The percentage of Ferric Oxide $\mathrm{Fe}_{2} \mathrm{O}_{3}$ was low in RHA higher in OPC. The $\mathrm{CaO}$ in the RHA is less than that in the OPC and it is one of the most important oxide responsible for the formation of alite and belite which contribute to the early and later strength of concrete. High magnesia as seen in OPC contribute to poor cast quality of concrete.

\subsection{Compressive Strength}

From the results in Table 3 above, it is evident that the percentage of RHA increases with decrease in Compressive Strength, which may be attributed to the reduction in the cementitious properties of the concrete paste. The higher volume of the RHA in the concrete matrix results to less by-product of hydration which would have acted as a binder. This reduced by-product increases the porosity of the concrete with resultant decrease in strength. The compressive strength of the samples was observed to increase with the addition of limestone powder. The addition of LS powder which improved the compressive strength is as a result of filler effect on the microvoids within the cement matrix by increasing the compactness of the mixture, improving the microstructure of the bulk paste matrix and transition zone which results to increase in compressive strength

\subsection{Flexural Strength}

From the table it is evident that the flexural strength of the concrete dropped with increase in the quantity of RHA. But this strength improved with the addition of 1-5\% LS. The highest value of flexural strength was found to be $6.43 \mathrm{~N} / \mathrm{mm}^{2}$. The flexural strengths of samples with $15 \%$ RHA5\%LS and $20 \%$ RHA7\%LS were far less than that of the 10\%RHA20\%LS. It is therefore recommended that the optimum replacement of RHA should not exceed $10 \%$ with about $2 \%$ LS.

\section{Conclusion}

The 28day curing Period of different samples of concrete cubes produced by adding varying percentages of RHA, LS and OPC gave a lowest compressive strength of $2.98 \mathrm{~N} / \mathrm{mm}^{2}$ for sample with 20\%RHA7\%LS73\%OPC and maximum compressive strength of $20.62 \mathrm{~N} / \mathrm{mm}^{2}$ for sample with $10 \%$ RHA2\%LS88\%OPC. Furthermore the flexural strength was at minimum for the sample with $20 \%$ RHA7\%LS73\%OPC which gave a value of $4.73 \mathrm{~N} / \mathrm{mm}^{2}$ and highest for $0(\mathrm{CTL})$ at $7.47 \mathrm{~N} / \mathrm{mm}^{2}$ though followed by 10\%RHA2\%LS88\%OPC sample which gave a value of $6.43 \mathrm{~N} / \mathrm{mm}^{2}$.

\section{REFERENCES}

[1] Barnbrock,G.et al (1979)laying floor screeds. British Cement Association.

[2] Robert G. Blezard. "The History of Calcerous Cements" in Hewllett, Peter C, ed lea's chemistry of cement concrete 4 ed. Amsterdam; Elsevier Butterworth- Heineman, 2004.1-24 Print

[3] Alfred F. Crider(1907) Cement and Portland cement materials of Mississippi. Mississippi State Geographical Survey Bulletin 1

[4] Singh, L.R et al (2004): Properties, Preparation And Reaction Of Concrete. Delmar Publishers Canada

[5] Della, M. Roy (1992): Advancement of Cement System, including CBC,DSP, MDF; 9th International Congress on the chemist of Cement, New Delhi.

[6] Mindess, S., Young J.F and Darwin D.(2003):Concrete; Second edition, Prentice Hall

[7] ASTM C 593-95(1978): Specifications for Pozzolans; West Conshohocken, Philadelphia

[8] Oyetola, E.B. and Abdullahi, M. (2004): The Use of Rice Husk Ash in Low-Cost Sandcrete Block Reduction; Leonardo Electronic, J. Practices Technol 


\section{AUTHORS' BIOGRAPHY}

Michael Iroh, B.Eng, M'.Eng., Iroh holds a bachelor and a master of engineering from the Federal University of Technology, Owerri, Nigeria. He is currently a lecturer in mechanical engineering, Abia State Polytechnic, Aba. His area of interest includes characterisation and processing of materials, corrosion science and engineering.

Engr. Prof. James E.O. Ovri,B.Sc,M.Sc,Ph.D,C.Eng., He is currently a professor of Materials and Metallurgical Engineering at the Federal University of Technology,Owerri,Nigeria. He holds a bachelor,master and a doctorate in Materials and Metallurgical Engineering. His research interests are high strength and high temperature materials,Corrosion science and engineering,mechanical testing and failure analysis.He is a chartered engineer.

Uchenna Nwachukwu, B.Eng. Nwachukwu holds a bachelor degree in Materials and Metallurgical Engineering from the Federal University of Technology, Owerri, Nigeria. He is currently serving his mandatory one year national service. His interest is in mechanical property evaluation of engineering materials. 